\title{
Renal dysplasia
}

INSERM

\section{Source}

INSERM. (1999). Orphanet: an online rare disease and orphan drug data base. Renal dysplasia. ORPHA:93108

Renal dysplasia is a form of renal malformation in which the kidney(s) are present but their development is abnormal and incomplete. Renal dysplasia can be unilateral or bilateral (see these terms), segmental, and of variable severity, with renal aplasia corresponding to extreme dysplasia. 